\title{
Regional differences in entrepreneurial perceptions and implications for the Romanian competitiveness policy
}

\author{
Mariana NICOLAE \\ Bucharest University of Economic Studies, Bucharest, Romania \\ mariana.nicolae@rei.ase.ro \\ Irina ION \\ Bucharest University of Economic Studies, Bucharest, Romania \\ irinazgreaban@yahoo.com

\section{Elena NICOLAE} \\ Bucharest University of Economic Studies, Bucharest, Romania \\ ela.nicolae@rei.ase.ro
}

\begin{abstract}
Understanding entrepreneurship as being spatially rooted transforms it in a regional and national competitiveness factor. Despite the increasing importance of the territorial dimension in supporting economic growth at policy and declarative levels, in practice, in Romania, the territorial structure and spatial organization of the economy contributes little to the national value added. In this context, we study regional differences in entrepreneurial initiative and perception and their possible impact on the national competitiveness strategy. We use primary data collected in three Romanian regions (Centre, North-East, București-Ilfov) and conduct a statistical analysis of the data. The results indicate different comparative regional profiles. The regional differences in the intentions, motivations, barriers and limitation for entrepreneurship confirm the theoretical view that personal motivations of becoming an entrepreneur are determined by environmental conditions. We conclude that the regional differences should be taken into account in the elaboration of the competitiveness policy, corroborated with the results of other similar studies.
\end{abstract}

Keywords: entrepreneurship, regional differences, competitiveness, spatial development, public policy, local environment.

Please cite the article as follows: Nicolae, M., Ion, I. and Nicolae, E. (2016), "Regional differences in entrepreneurial perceptions and implications for the Romanian competitiveness policy", Management \& Marketing. Challenges for the Knowledge Society, Vol. 11, No. 1, pp. 394-409, DOI: $10.1515 / \mathrm{mmcks}-2016-0005$.

\section{Introduction}

Since Schumpeter (1911), entrepreneurship is considered a significant factor of economic growth, and competitiveness by economists and public policy decision making factors, being also called the 'fourth' factor of production (Leff, 1979).

Entrepreneurship is currently understood as a reflection of the local competitive advantages and disadvantages of the external environment or, in other words, of the overall microeconomic business, social and economic conditions. The networks of local systems, competitors, customers, suppliers and specialized institutions are part of the external environment which can stimulate or jeopardize entrepreneurship. Understanding entrepreneurship at regional level as an "approximation of the 
economy's capacity to dynamically face the multiple challenges of the economic opening", Cojanu (2006) links entrepreneurship with territorial development and competitiveness. Still, in spite of this intriguing and vague relation between entrepreneurship and competitiveness, however in clear connection with the lack of primary data on entrepreneurship, have left this topic understudied in the literature, especially in Romania. Few authors examine the implications of the differences in entrepreneurship for macroeconomic policies, such as Cojanu (2006).

From a policy perspective, the situation is also problematic. The lack of efficiency of public policies for improving the conditions for entrepreneurship development has been signaled in many academic and non-academic environments. The Romanian public policy has lacked a structured and coherent approach to sustaining the local entrepreneurship environment, which negatively impacted economic growth (Armeanu et al., 2015), as well as local development and competitiveness. This governmental difficulty to efficiently implement public policies overlaps with a fragile entrepreneurial culture (Ion and Nicolae, 2012a), in which new businesses have emerged despite the institutional limitations. In rural areas, in which development is invariably determined by the pervasive influence of a small and micro-scale entrepreneurial business (Nemirschi and Crăciun, 2010), the results of an inefficient public policy are even more severe.

The Romanian National Competitiveness Strategy 2010-2020 (RNCS) signals that public policy on competitiveness ignores the effects of spatial agglomerations and does not have mechanisms to supervise the spatial effect of investments. This, despite the fact that the idea and practice of defining socio-economic development strategies in terms of geographical areas is not new in Romania. This practice is a result of the implementation of European Union policies in Romania, which aim at economic, social and territorial convergence and cohesion. At European level, the emergence of authentic territorial economies with planning and decision making responsibilities, has acquired a significant importance. This importance increased as the financial framework 2007-2013 established territorial cooperation as one main objective of the cohesion policy. In the case of Romania, there are significant territorial economic development gaps and differences between Romanian regions but also between Romanian and European regions.

In this context, we study regional differences in entrepreneurial initiative and perception and their possible impact on the national competitiveness strategy, as formulated in the Romanian National Competitiveness Strategy 2010-2020. We use primary data collected in March-April 2012, in three Romanian regions (București-Ilfov, Centre, North-East) regarding entrepreneurship, in the context and with the financing of the European project eLife, ID 61758, coordinated by the Bucharest Academy of Economic Studies. The project eLife - The Development of Innovation, Creativity, Responsibility and Sustainability of Romanian Entrepreneurship, ID POSDRU/92/3.1/S/61758, was financed through the European Social Fund and was carried out between December 2010 and November 2013. The project was implemented in three Romanian regions: București-Ilfov, Centre and North-East. The project started from an analysis of the situation of entrepreneurship development in the three regions covered, the provision of training for actual and potential entrepreneurs, the organization of study visits in France for the transfer of good practices in supporting entrepreneurship and the provision of face to face and online consultancy for entrepreneurs. 
The type of the sample used in the surveys was random, stratified, by stages, for all the categories of respondents, except for potential entrepreneurs, for which the sample was both random and snowballing. Approximately $90 \%$ of the questionnaires were applied face to face and $10 \%$ on-line.

The sample included four types of respondents: (a) potential entrepreneurs 1,200 employees, 400 employees per region;(b) potential entrepreneurs - 360 persons, 120 persons per region, of which $50 \%$ students, $30 \%$ unemployed persons, $10 \%$ military reserve persons, $10 \%$ retired persons; (c) current entrepreneurs/business owners - 360 persons, 120 persons per region; (d) SMEs managers - 360 persons, 120 persons per region.

In our study, due to space limitations, we only investigate the perception of employees as potential entrepreneurs and the one of current entrepreneurs or business owners.

\section{Theoretical background: entrepreneurship and competitiveness}

Entrepreneurship is currently considered a panacea for solving economic, social and environmental challenges. According to Smart and Conant (1994), it is a goal-oriented process that involves identifying market opportunities, managing resources to exploit these opportunities and adapting to the environment to achieve the desired results, in parallel with taking the risks of failure.

Entrepreneurship has consolidated itself as a distinct discipline in social sciences in the 80s and 90s, but it gained legitimacy in the latest 2000s (Meyer, 2014). Still, its intellectual roots are older and they can be traced back to Richard Cantillon's work Essai sur la Nature du Commerce en Général (1755). Cantillon identified the entrepreneur as a distinct type of economic agent. However, it was Schumpeter (1911) the one that theorized the analysis of the entrepreneurs, considering them a source of innovation and consequently of economic growth, viewed as a process of creative destruction. The representatives of the Austrian School of economic thought have consolidated the theoretical role of the entrepreneur in the economy, through the contributions of Carl Menger, Ludwig von Mises, Friedrich von Hayek and Israel Kirzner (1973).

In Romania, academic research on entrepreneurship seems to follow the international path and to be diversifying and multiplying, including contributions of authors such as Chelariu et al. (2008), Lafuente and Vaillan (2008), Lafuente and Rabetino (2011), Dodescu et al. (2011), Mihalcea et al. (2012), Panc et al. (2012), Nicoale et al. (2012), Armeanu et al. (2015), Brancu et al. (2015) or Hatos et al. (2015).

In our research, we follow one of the three main broad research directions in entrepreneurship identified by Stevenson and Jarillo (1990): a) why entrepreneurs act, b) what happens when entrepreneurs act and c) how they act. We are interested more in why entrepreneurs act, i.e., on their motivations. These motivations can be divided into two types: a) psychological traits of the individual, described by attributes such as creativity, daringness, aggressiveness or risk taking (Stevenson, Jarillo, 1990) and b) the characteristics of the local, external, environment.

The environment as an entrepreneurship motivator was set by McClelland (1961) and developed by authors such as Greenfield et al. (1979) and Pennings (1982). According to this view, personal motivations are determined by environmental conditions. While an entrepreneur has certain innate characteristics, he/she is also the product of the economic, institutional and cultural environment (Brancu et al., 2015). This advocacy view has obvious implications for public policy and has become the most common approach in current research. A consistent body of empirical research confirms 
this theoretical view. One example for Romania is the study performed by Brancu et al. (2015) that aimed to test if cultural differences explain different entrepreneurial behaviors of Romanian and Islandic students and revealed that those differences were explained by macroeconomic variables such as the level of development, the quality of the institutional context or the support given by national policies, and not to cultural differences per se.

At macroeconomic level, considering entrepreneurship a growth factor has transformed it also in a competitiveness factor. Rooted in the contributions of the new trade theories, the competitiveness theory of Michael Porter is the most recent and accepted theory that explains national competitiveness internationally. The theory is an integrative effort to jointly analyze firms, industries and countries. According to Porter's theory, there are two foundations of a country's productivity and prosperity: microeconomic and macroeconomic competitiveness. Macroeconomic competitiveness is related to social infrastructure, political institutions and macroeconomic policies. Microeconomic competitiveness is generated by the quality of the microeconomic business environment, cluster developments and the sophistication of company operations and strategy. In Porter's theory geographical location is one of the most important issues in defining competitiveness. For him social capital is formed within the boundaries of a region, while knowledge and knowledge spillovers are also rooted in the region. Transaction costs are also regional and economies of scale are internal and external to the specific local environment (Karlsson and Dahlberg, 2003). Location is, therefore, a decisive competitiveness element for business success, as it is dependent on several local issues such as the interaction with competitors, access to providers, research institutes, together with all other particular aspects of the local, geographical business environment. Geographical location becomes increasingly important in a more interconnected and distanceless world. As a result, there is an increasing specialization of economic life and activity in territorial clusters of firms, with a new role for regions in economic development. Regions have started to be considered a source of increasing returns and hubs of knowledge (Cambridge Econometrics, 2003).

The importance of location has two main interrelated effects which we are of interest for the present study: the shift form national competitiveness to regional competitiveness and the need to understand the importance of the local business environment in entrepreneurship development. In what concerns the first issue, the attention of academics has indeed shifted from the competitiveness of nations to regional competitiveness, with an increasingly broad consensus on the role of regions as "key location for organizing and managing economic growth and wealth creation" (Kitson et al., 2004).

The concept of entrepreneurship also started to be viewed as spatially rooted, being a complex reflection of the local competitive advantages and disadvantages of the external environment. This is because the success of local companies that have their own local productive system is dependent on the specific characteristics of their immediate environment (Arzeni and Pellegrin, 1997). As explained by Cojanu (2006) "the development sources are regionally divided in a strong relation to the local abilities to put at good use certain common determining factors of the entrepreneurial initiative". As mentioned earlier, this approach links the motivation of entrepreneurs with the local external business and socio-economic factors of the environment, such as the regional infrastructure, the cultural level or political dynamics. This view actually reinforces the idea that entrepreneurship is also a regional phenomenon and not only a national one. 
Empirical research in the 80s on the influence of entrepreneurship for regional development lead to divergent findings (Audretsch and Keilbach, 2004). Still, more recent studies of the 90 s and early 2000s seem to confirm a positive relation between the two variables, which is explained by the authors by an increased role of entrepreneurship as an engine growth. To give some examples of empirical studies, Baptista et al. (2008) test whether there is a positive relationship between increases in new firm start-up rates and subsequent employment growth at the regional level for Portugal. Their results confirm the relation between entrepreneurship and regional employment. Fotopoulos (2012) tests the effect of entrepreneurship on the regional economic growth of European regions, finding it to be a positive one. Noseleit (2013) explains the role of entrepreneurship in economic growth by relating it to the fact that entrepreneurship reallocates production factors across sectors. His empirical tests on German data from 1975 to 2002 confirmed that sectorial reallocations are an important means for transforming entrepreneurial activity into growth.

Romanian entrepreneurship seems to be unevenly developed across the country's regions. Cojanu (2006) studied this issue and identified three types of clusters of counties from the point of view of the local conditions in which entrepreneurship can be developed. The first type of cluster shows a favorable climate for entrepreneurship and business development and includes counties such as București, Bacău, Iaşi, Suceava, Galati, Prahova, Dolj, Timiş, Bihor, Cluj, Brașov. Another type only shows a satisfactory potential for entrepreneurship to growth (such as Arges). A third type of cluster is that of locations that lack the conditions for business and entrepreneurial growth, such as Brăila, Tulcea, Vrancea, Călăraşi, Giurgiu, Ialomița, Caraş-Severin, Bistrița-Năsăud, SatuMare, Sălaj, Covasna and Harghita counties. Another study reached a similar conclusion: entrepreneurship is unevenly developed across Romanian regions and counties, in terms of a series of entrepreneurship indicators, such as the percentage of persons trying to open a business in Romania, registration of start-ups or the territorial distribution of Romanian SMEs (Nicolae and Ion, 2012a).

\section{The Romanian competitiveness policy - the territorial dimension}

Territorial imbalances, in terms of income, entrepreneurship, technological endowment or human capital are a characteristic of the Romanian economy, as stated earlier. In order to understand how the competitiveness policy aims to tackle some of these imbalances, we have analyzed the Romanian National Competitiveness Strategy 20102010 (RNCS), focusing on the territorial dimension of this strategic document. Interestingly, one of the challenges to which the RNCS aims to offer solutions is entrepreneurship. Moreover, the vision of the RNCS is to "develop a competitive business ecosystem, based on a stable regulatory environment, focused on entrepreneurship, innovation and creativity that emphasizes trust, efficiency and excellence that can place Romania in the first 10 economies at European level". In what concerns the territorial dimension or the regional side of competitiveness, the RNCS offers several conclusions. According to the RNCS, the competitive advantages are diversified in some regions, such as South, North-West and Centre due to diverse economic structures and are more homogenous in other regions, such as South-West, South-East and West. Importantly, the territorial structure and spatial organization of the economy adds little to the national value added, with urban Centre s that influence insignificantly the economic activities networks. Moreover, European Funds' investments are planned for cities and companies and not on integrated intervention 
areas, while the local administrative structures accomplish more bureaucratic roles than competitive development roles.

These conclusions constitute good premises for the further planning of regional competitiveness, as generally recognized both in the administrative and academic environments. They also represent a first step for a type of planning that follows a territorial approach. Hopefully, the further operational Action Plan of the RNCS will follow a territorial pattern. Based on the primary research conducted on entrepreneurship in the three regions mentioned, we will try to draw some useful conclusions for such an approach.

\section{Regional differences in entrepreneurial perceptions in Romania}

We will first analyze the answers of the sub-sample of employees, in their quality of potential entrepreneurs. Firstly, we observe important differences by regions in the intention to open a business, with $52.4 \%$ of respondents showing their intention to become entrepreneurs in the București - Ilfov region, and only $42.5 \%$ and $39.8 \%$ in the Centre and regions North-East respectively. From the very beginning, there is a somehow expected gap in the willingness to become an entrepreneur.

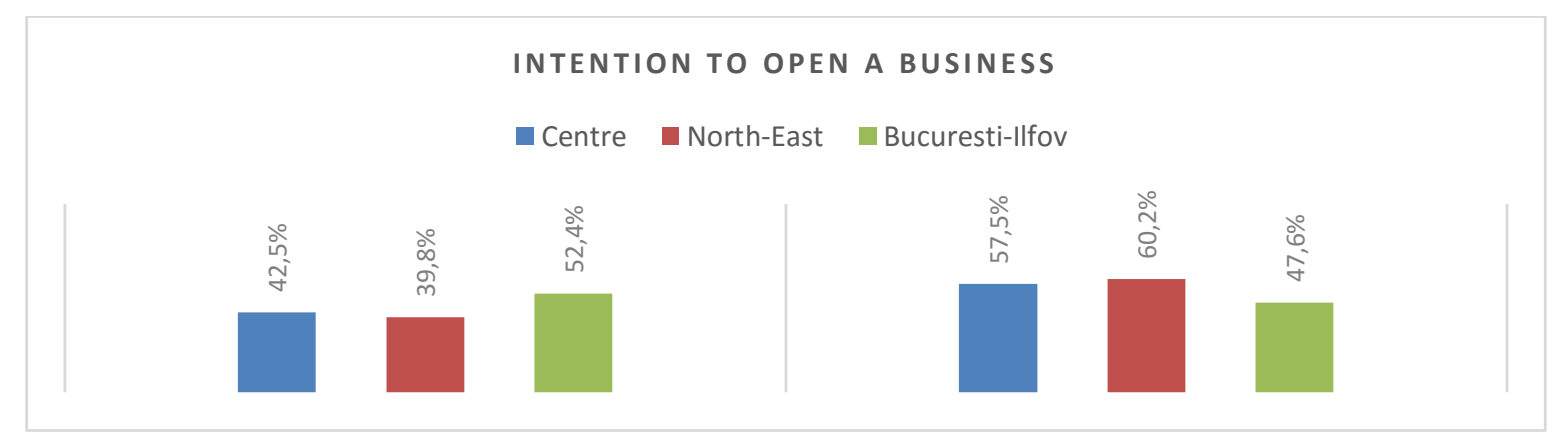

Figure 1. The intention to open a business (potential entrepreneurs)

Source: Database of the eLife project

In order to better understand what the main barriers to begin a new business are, we take a look at some of the reasons people do not start their own reasons.

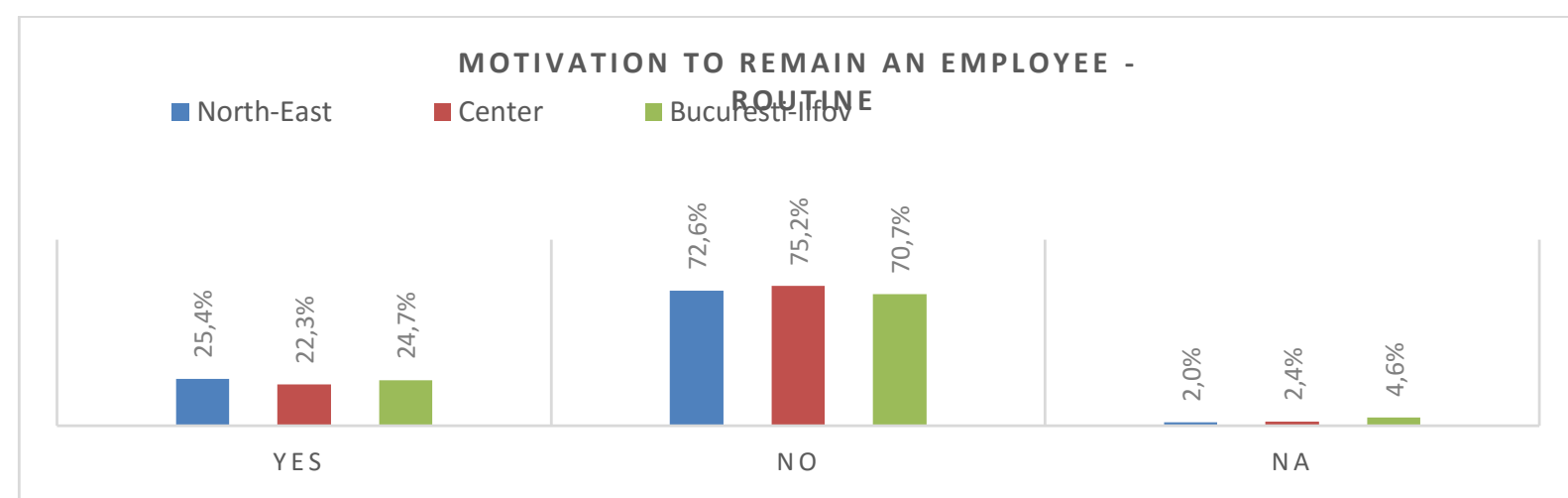

Figure 2. Routine as a motivation to remain an employee (potential entrepreneurs) Source: database of the eLife project.

One important barrier to entrepreneurship is that, as employees, respondents valued their day to day routine activity, as it reduces the need to be alert and to adapt to new, unforeseen, unfamiliar and stressful situations. These turbulences contributed to the decrease of their appetite to become entrepreneurs. The perception of routine is 
MMCKS different in the three regions. 25.4\% of the North East region respondents considered that routine is a good reason to remain an employee and not to start a business, 400 meanwhile in the other two regions the percentage is lower $(22.3 \%$ in the Centre region and $24.7 \%$ in București-Ilfov). This shows that in the Centre and București - Ilfov respondents are more open to entrepreneurial challenges. Despite the fact that the perception of routine is more an internal barrier to entrepreneurship, based on the psychological attributes of the respondents, the evaluation of routine is still relevant for policy development, as it gives an idea about the appetite for risk taking in the region.

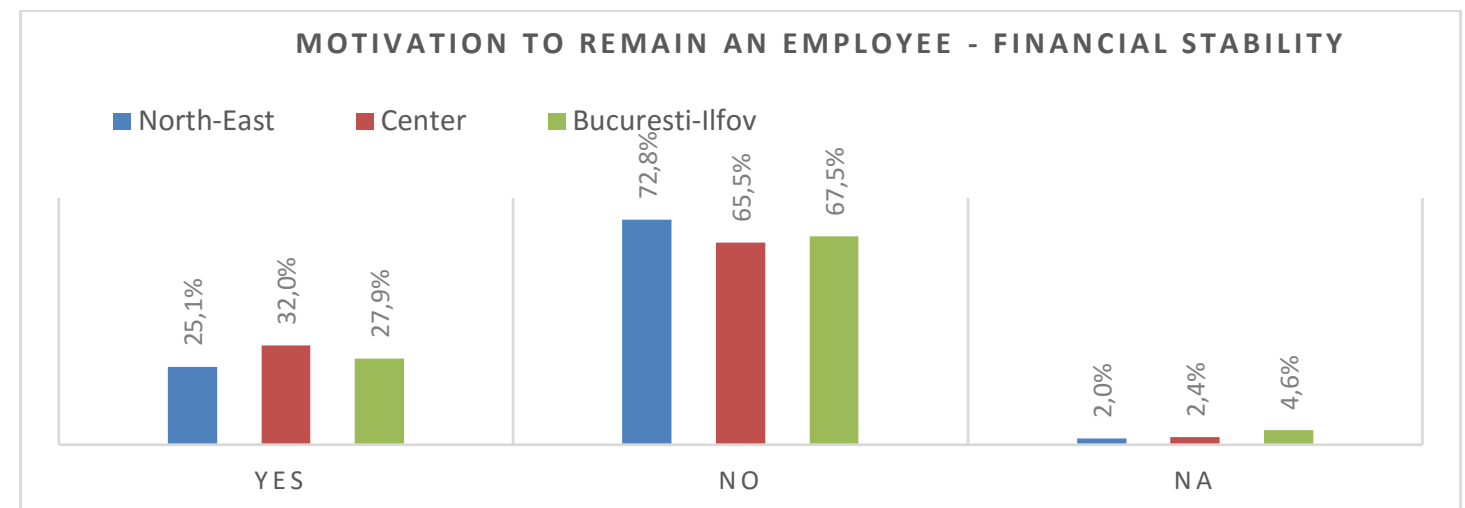

Figure 3. Financial stability as a motivation to remain employees (potential entrepreneurs) Source: database of the eLife project.

Another barrier to become an entrepreneur is the appreciation of financial stability, as an attribute of having a job (and not a business). $32 \%$ of the Centre region respondents believed that financial stability as an employee is a good reason not to open a business, meanwhile only $25.1 \%$ of respondents in the North East and $27.9 \%$ in the București - Ilfov region shared this idea. This big discrepancy between the Centre and North East regions is probably explained also by the differences in salary levels in the two regions, as conditions of the external environment that influence the attitude on entrepreneurship.

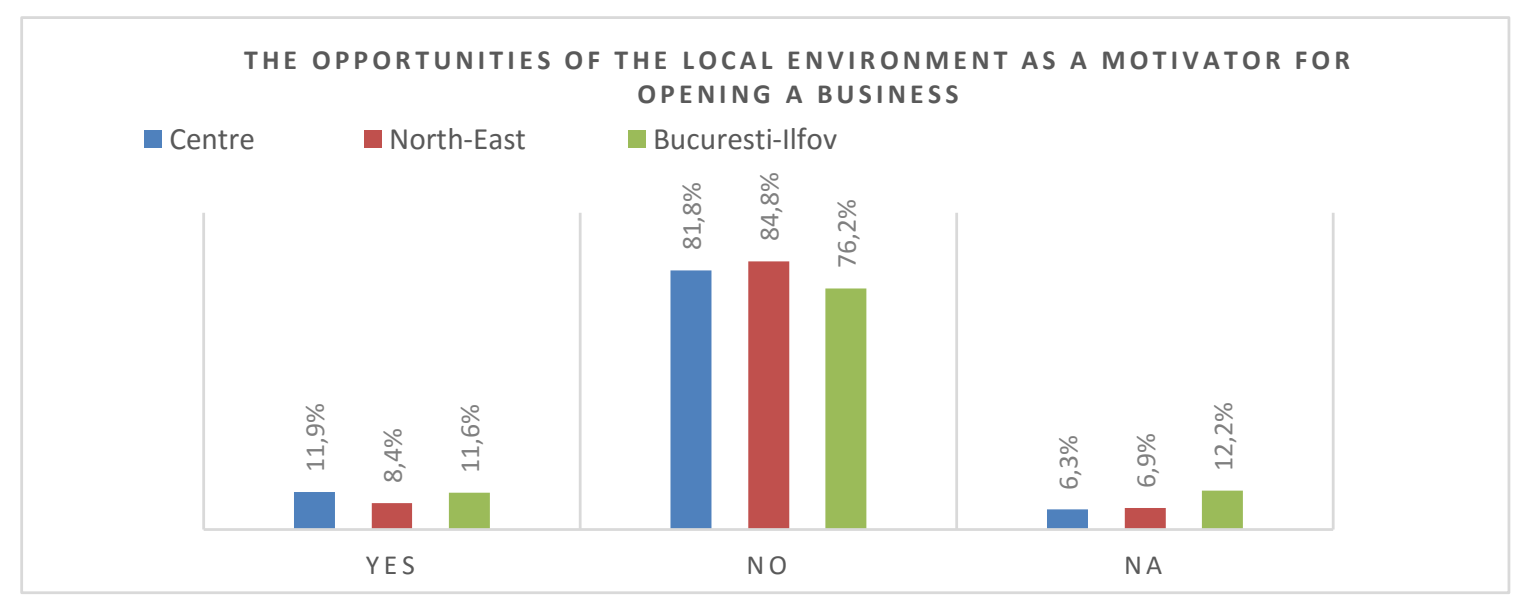

Figure 4. The opportunities of the local environment as a motivation to open a business (potential entrepreneurs)

Source: database of the eLife project

In what concerns the local environment and local opportunities to open a business, the perception on its attractiveness is very low in the three regions. Both in the 
Centre and the București - Ilfov regions around 11\% of the respondents consider that the opportunities of the local environment are a good reason to start a business, while only approximately $8 \%$ of respondents share this idea in the North-East region. In what concerns the evaluation of the national and regional contexts, the results are mixed. Still, in all the three regions, around $40 \%$ of respondents share a total or a partial agreement of the fact that there are enough opportunities to start a business in the region. The evaluation of the national environment is similar, but with higher percentages of positive answers, reaching $47.5 \%$, in the North-East region.

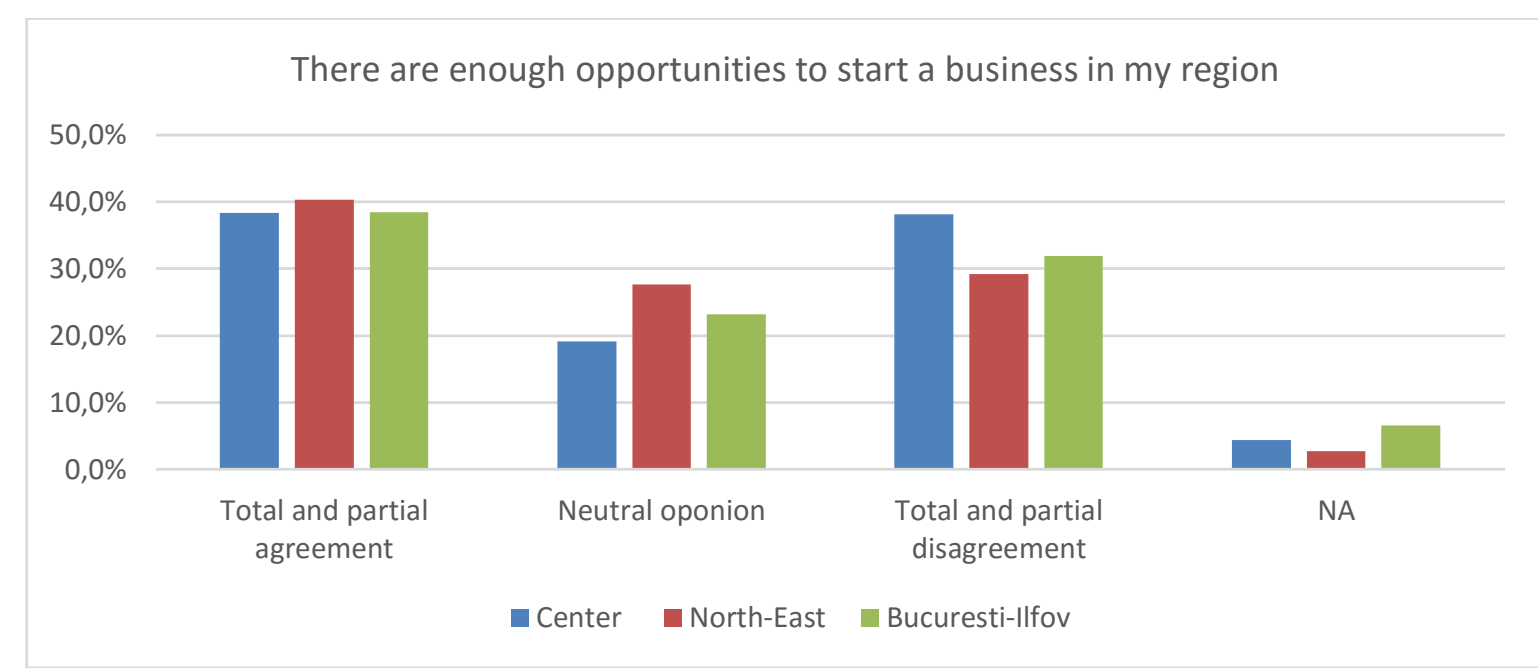

Figure 5a. Opportunities to start a business regionally and nationally (potential entrepreneurs) Source: database of the eLife project.

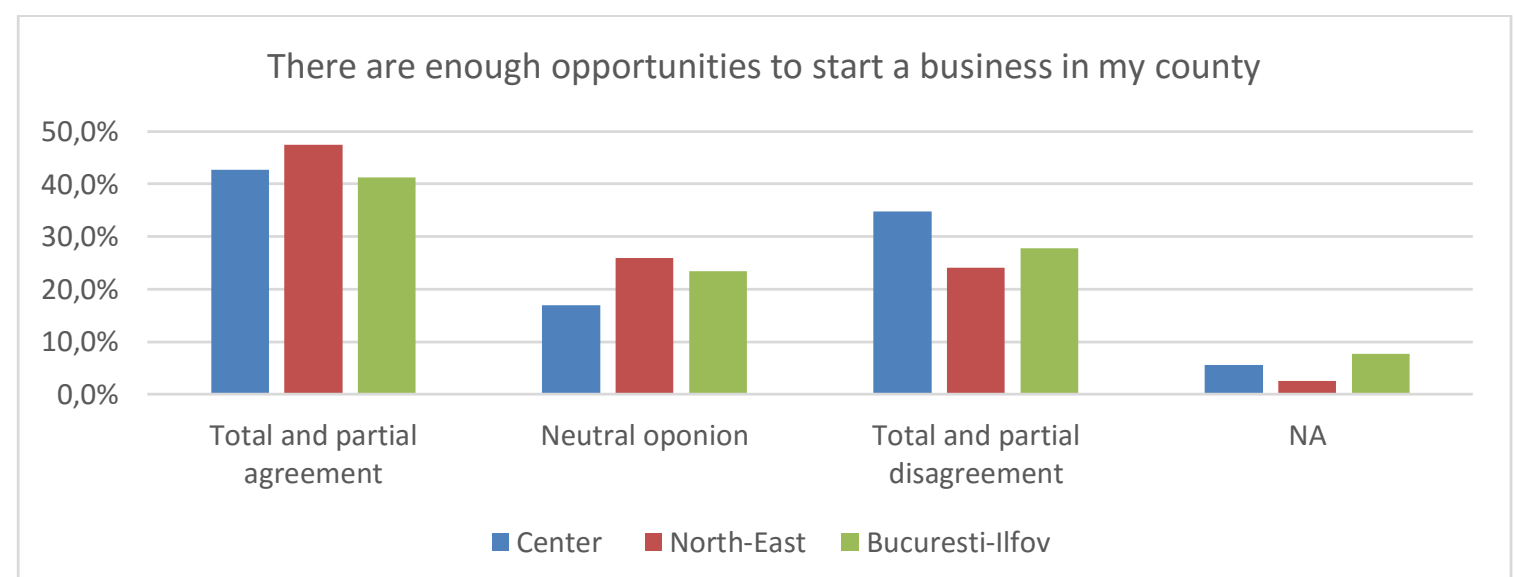

Figure 5b. Opportunities to start a business regionally and nationally (potential entrepreneurs) Source: database of the eLife project.

The perceptions of the regional limitations of entrepreneurship are relatively divergent for the three regions. Meanwhile the lack of financial resources is the main limitation for the Centre and București-Ilfov regions, for the North-East region financial resources and technological resources are considered equally important. What is also significant is the high percentage of respondents that agree on the limited financial and technological resources in the North-East region - $73.1 \%$, with only $46.4 \%$ of respondents that consider that human resources are limited. The situation is much better for the Centre region, in which only $65.3 \%$ of respondents believe financial resources are limited, $41.5 \%$ that technological resources are limited and $27,2 \%$ that human resources are limited. 
Entrepreneurship in the region is influenced by limited financial resources

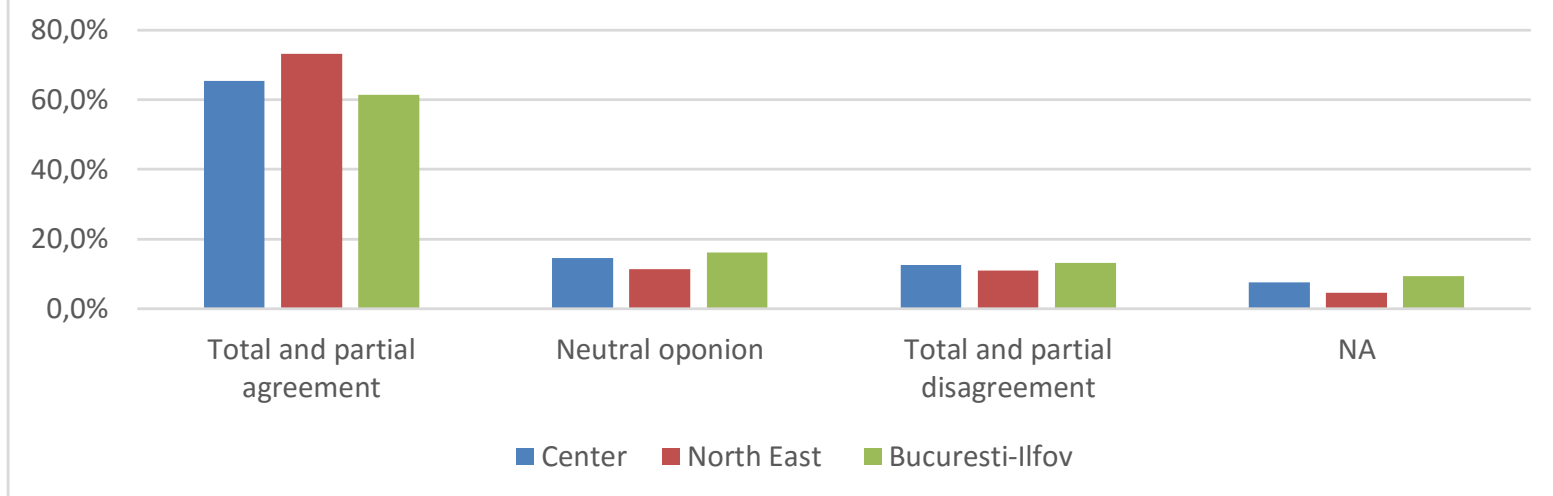

Figure 6a. Regional limitations on entrepreneurship (potential entrepreneurs)

Source: database of the eLife project.

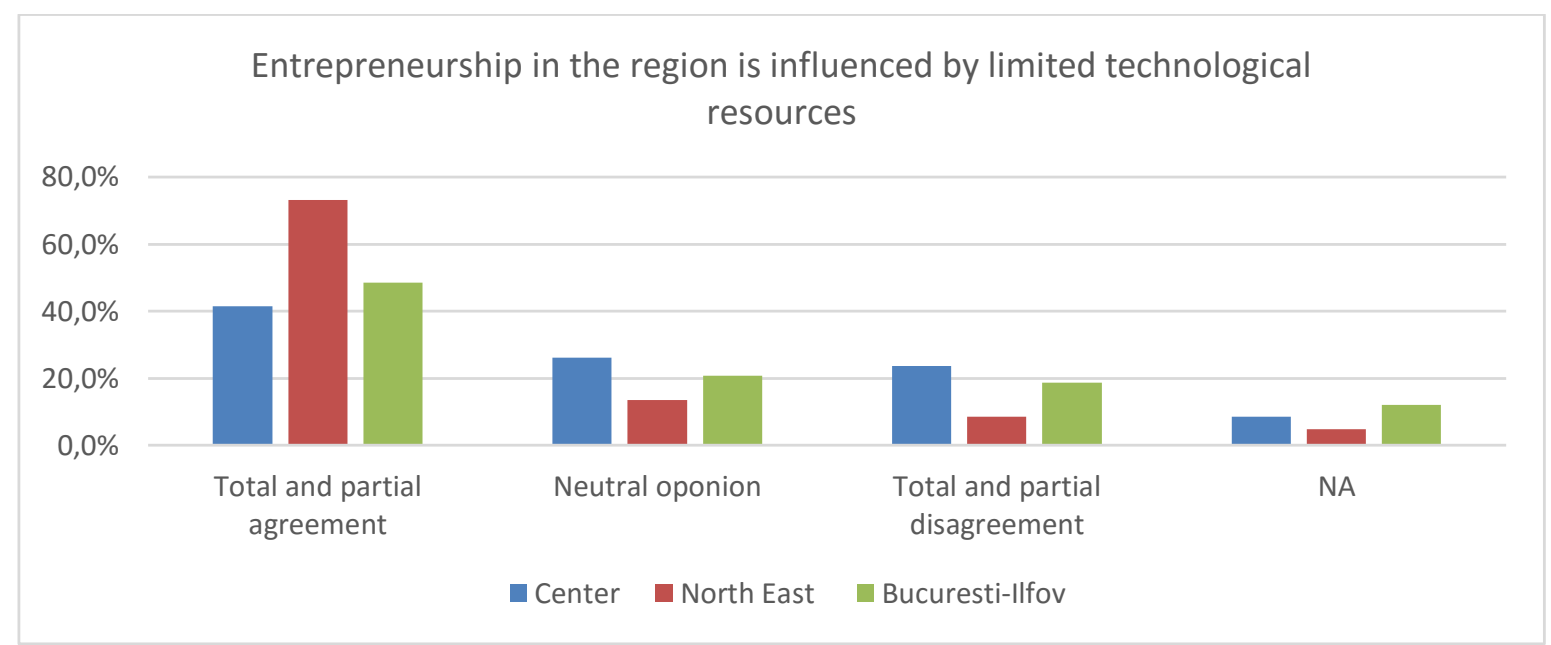

Figure 6b. Regional limitations on entrepreneurship (potential entrepreneurs)

Source: database of the eLife project.

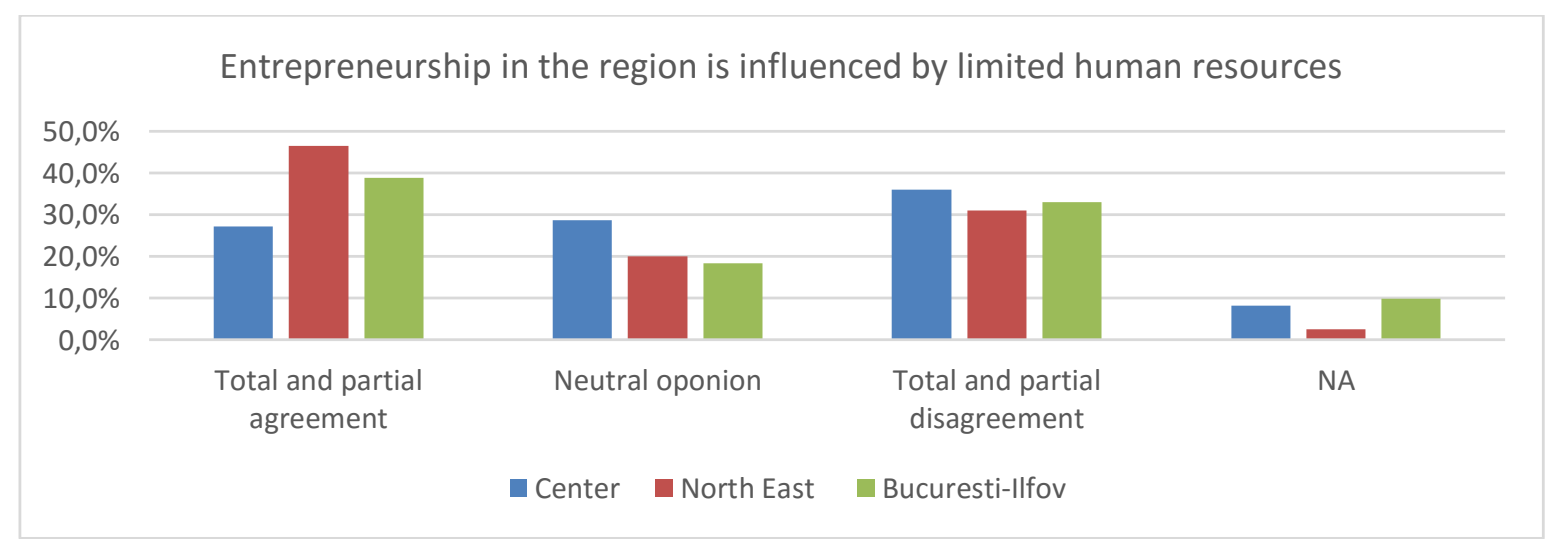

Figure 6 c. Regional limitations on entrepreneurship (potential entrepreneurs)

Source: database of the eLife project.

In what follows we will analyze regional differences in entrepreneurial perception for the subsample of current entrepreneurs.

In what concerns their intention to open a new business, $42.1 \%$ of the BucureștiIlfov respondents manifest this intention, compared to only $22.5 \%$ in the Centre region 
and only $33 \%$ in the North-East one. As compared to answers of potential entrepreneurs, the percentages are slightly lower. Still, the answers confirm the same pattern registered for potential entrepreneurs - a pattern of regional differences in the intention to open a business. What is different for current entrepreneurs versus potential ones is a wider gap in the regional differences. There is a 9.1 percentage point difference in the intention to open a new business between București-Ilfov and NorthEast and 19.6 percentage points difference between București-Ilfov and the Centre. This is probably because the opinion of current business persons is much more informed and therefore relies on very specific conditions for entrepreneurship at local and regional levels. In other words, we believe that this differences might signal very different evaluations of the local contexts conditions.

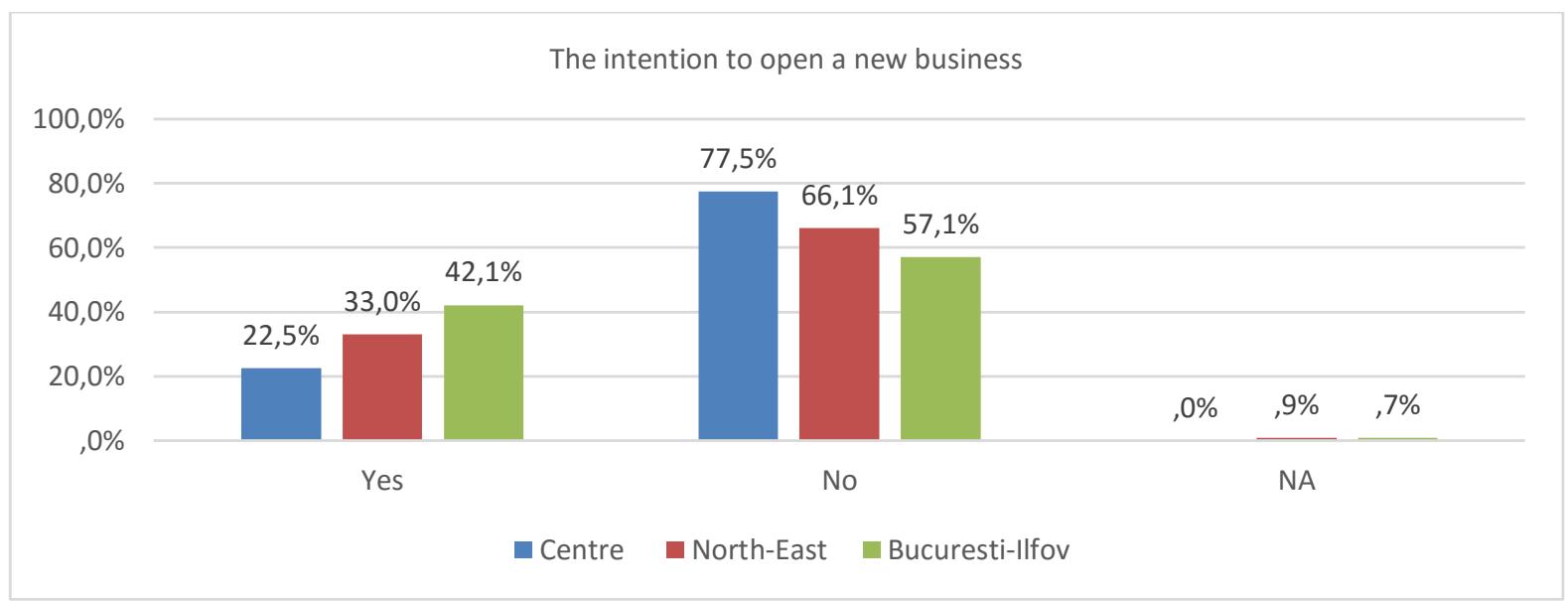

Figure 7a. The intention to open a new business (current entrepreneurs)

Source: database of the eLife project.

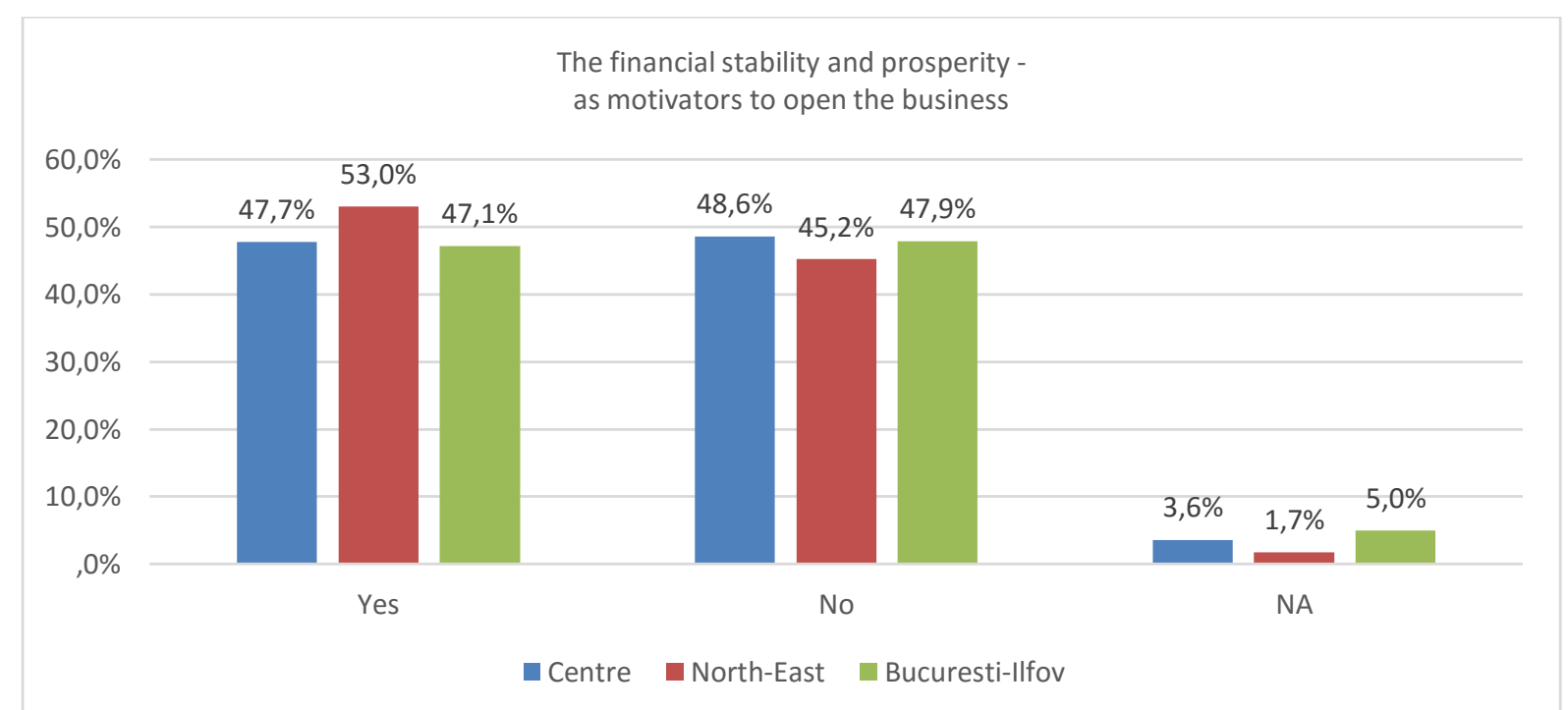

Figure $\mathbf{7 b}$. The financial stability and prosperity as motivators to open a business (current entrepreneurs)

Source: database of the eLife project.

In what concerns the financial stability and prosperity as motivators to open a new business, $53 \%$ of North-East region are motivated by it, meanwhile only around $47 \%$ of respondents share this motivation in the other two regions. 


\section{MMCKS}

404
The opportunities of the local environement -

as motivators to open the business

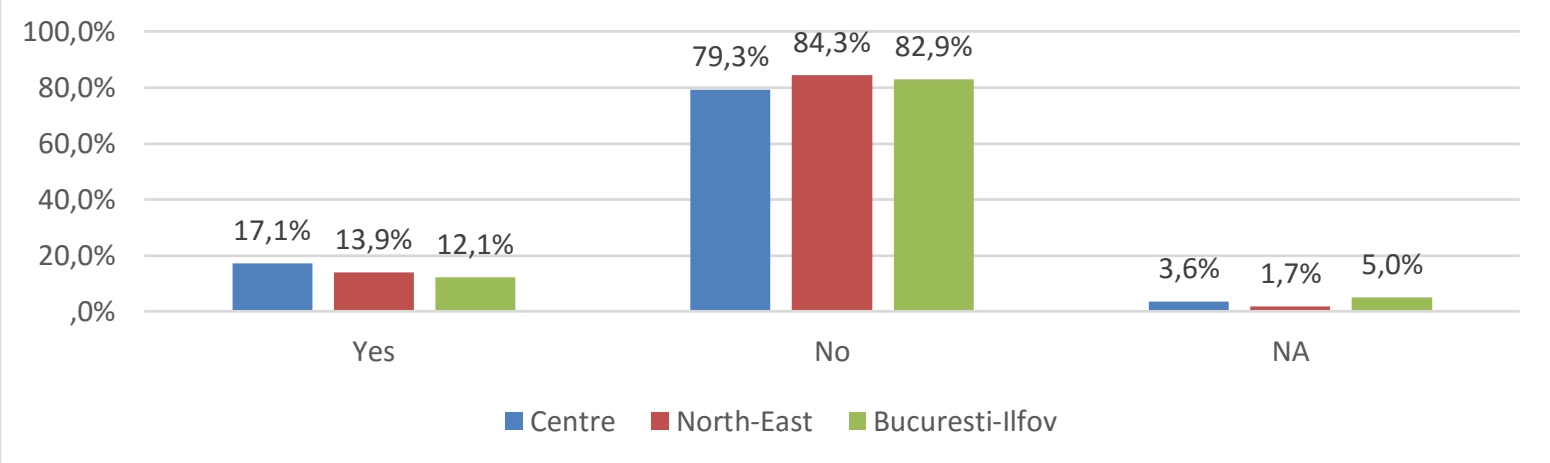

Figure 8. The opportunities of the local environment as motivators to open a business (current entrepreneurs)

Source: database of the eLife project.

Asked if the local environment offers enough opportunities to open a business, $17.1 \%$ of respondents answered positively in the Centre region, as compared to $13.9 \%$ and $12.1 \%$ in the North-East and București-Ilfov regions. Again, the gap between the Centre and North-East is relatively high, of 5 percentage points specifically, showing again how important the local environment is in boosting or limiting entrepreneurship.

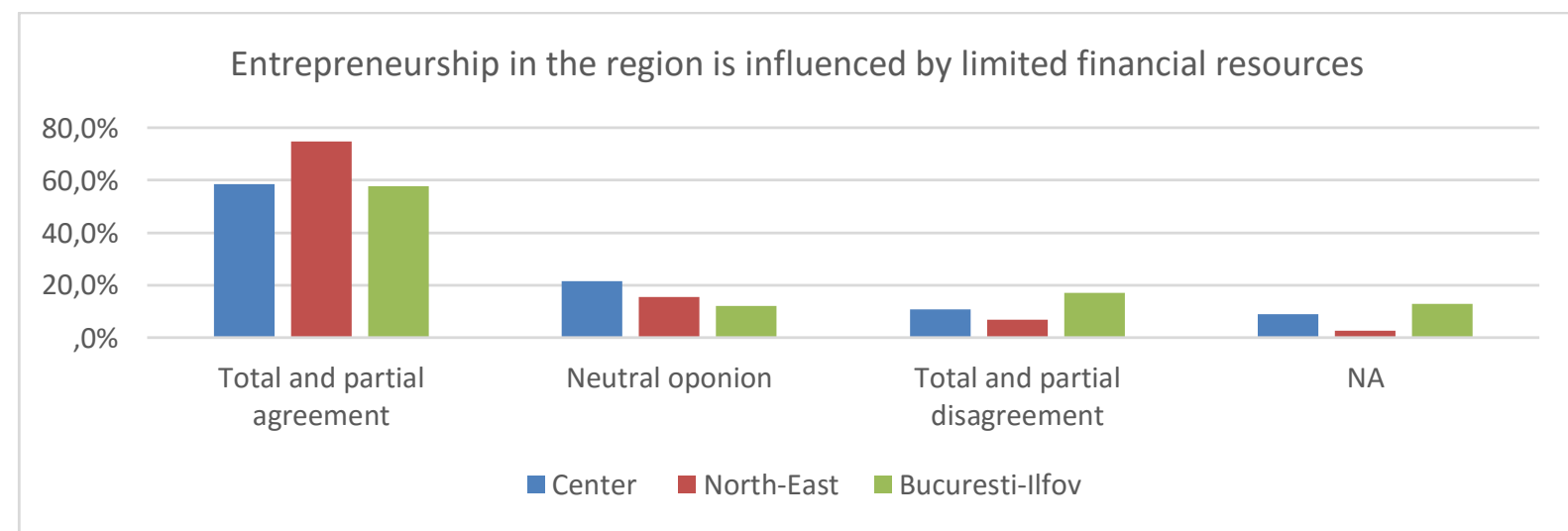

Figure 9a. Regional limitations on entrepreneurship (current entrepreneurs)

Source: database of the eLife project

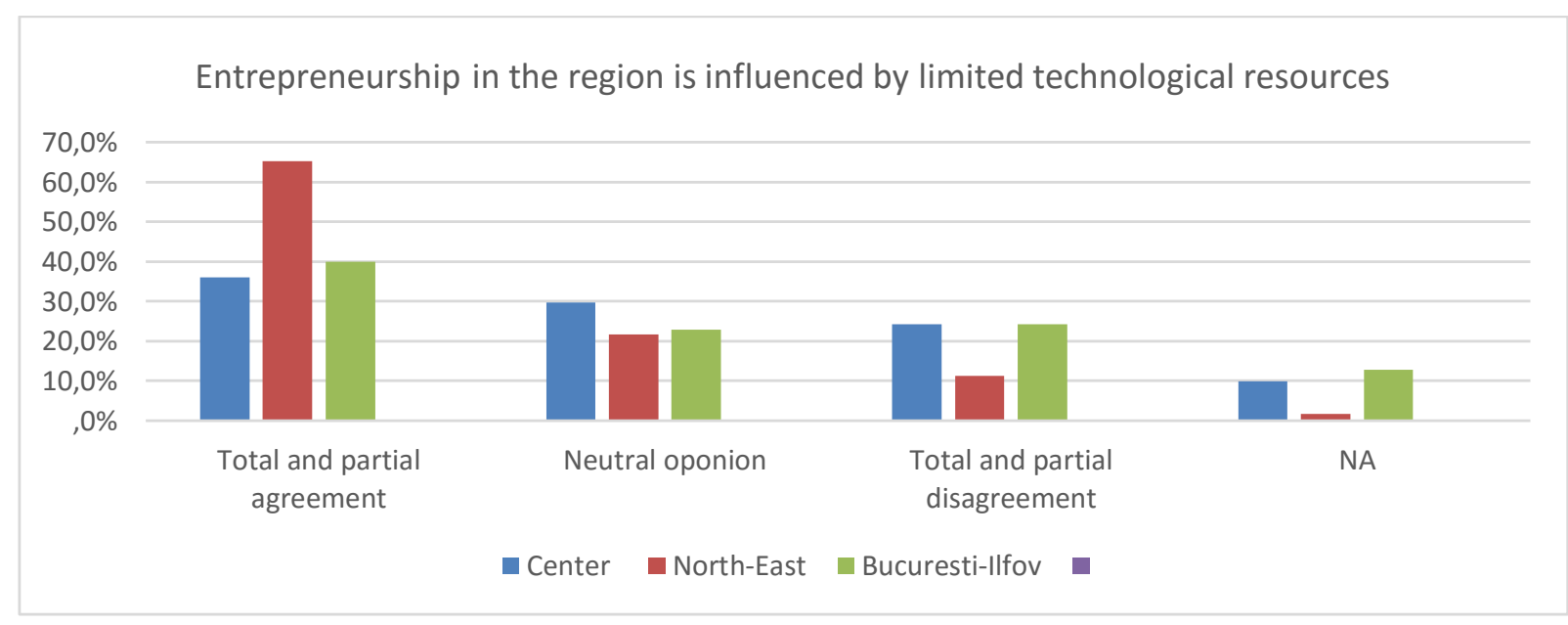


Figure 9b. Regional limitations on entrepreneurship (current entrepreneurs)

Source: database of the eLife project.

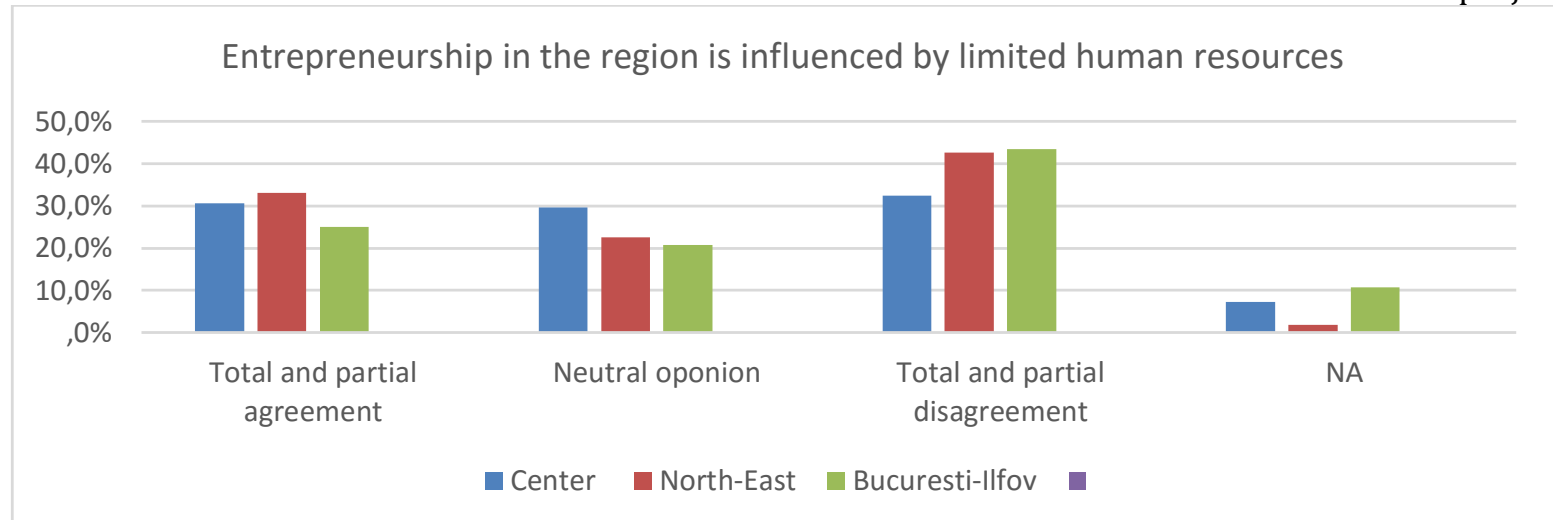

Figure 9c. Regional limitations on entrepreneurship (current entrepreneurs)

Source: database of the eLife project.

Concerning the regional limitations perceived as barriers to start a new business, the scarcity of financial resources is considered the most important barrier, followed by the lack of technological resources and financial resources respectively, in all the three regions, confirming the results from the sub-sample of potential employees. Also, the differences between the North-East region and the Centre and București-Ilfov regions are visible again, in the sense of a North-East region with comparatively more business resources missing, and thus, less opportunities to start a business.

\section{Implications for the Romanian regional development strategy}

The results of the primary research regarding entrepreneurship show that there are generalized differences in entrepreneurship perceptions between the three regions included in the study: București-Ilfov, Centre and North-East. Those differences are in essence a reflection of the territorial imbalances that have characterized the Romanian economy in terms of several aspects and have, among others, historical causes. As shown by various researchers, some of those aspects are, for example, the level of incomes or the availability of human, technological and financial resources. Antonescu (2012) concludes that in Romania the disparities among the regions of development have increased in terms of economic performance in the period 2000 - 2009 with the highest discrepancy between București-Ilfov, on the one hand, and the other regions on the other. Those differences affect the intention to open a business, of both potential and current employees, thus limiting in some cases (repeatedly in the North-East region) the possibility of the local economy to grow based on entrepreneurship.

An important characteristic of the micro and regional environment that shapes the perception on entrepreneurship is the level of salaries. In the Centre region, higher salaries are probably incentives for a raising ambition to achieve an even better life. Meanwhile in the other two regions, especially in the North-East one, employees are probably satisfied with the current income not because they are high enough, but because their current financial situation and social status do not allow them to establish ambitious or at least challenging targets such as becoming business persons.

Another characteristic of the local environment that influences entrepreneurial activity is the perceived possibility to obtain financial stability and prosperity through entrepreneurship. If in the North-East region those possibilities represent motivations to open a new business for $53 \%$ of the respondents, in the other two regions only around $47 \%$ of the respondents share this motivation. The relatively high difference 
MMCKS between the North-East and the Centre and București-Ilfov regions could be explained through the lack of business and/or personal stability perceived in the North-East region, due to a poorer economic context, as compared with the other two regions. Prosperity, on the other hand, in the regions in which it is probably lacking, becomes a more targeted objective and a strong motivator for business development. Still, this motivation alone cannot provide the access to the necessary resources to open and develop a business in an environment in which business conditions are not relatively appropriate. The authors argue that, in this case, quite the opposite is true: more public support is needed to boost entrepreneurship by improving local environmental conditions.

Comparing the evaluation of the local environment with the one of the regional and national environments makes it clear that respondents share a much better image and perception of the last two. This signals the need to attach more importance to the local microenvironments in which the business develops, as currently those microenvironments are perceived as offering almost no business opportunities. Small actual and potential entrepreneurs need a competitive and at the same time a nurturing and healthy microclimate that favors entrepreneurial activity. The perceived attractiveness of the local context is one of the main motivators to start a business, but unfortunately in all the three regions, in various degrees, the results show that the local contexts are far from being attractive.

The important differences in the perception of regional limitations on entrepreneurs reconfirm the deep development discrepancies and the unequal distribution of the factors of production in Romania. The responses signal also a technological gap between the North-East region and the București-Ilfov and Centre one, with $73.1 \%$ of respondents indicating that technology resources are scarce, as compared to $41.5 \%$ and $48.5 \%$ respectively.

The results support the view that perceived local and regional business conditions influence the willingness to open a new business and the overall perceptions on entrepreneurship. The microeconomic business environment is represented by those business and economic conditions that interact directly with the current and potential entrepreneurs, thus modeling their entrepreneurial behavior. In their turn, those regional differences have to be reflected in different competitiveness and development spatial approaches to public policies.

The results obtained indicate different comparative regional profiles of the three regions studied from the point of view of our research - perceptions of entrepreneurship and their influence on the Romanian competitiveness policies.

The București-Ilfov region is the region in which more employees - potential entrepreneurs - and more current entrepreneurs intend to open a new business. If potential employees are able to identify local business opportunities in a relatively high percentage (as compared to the other regions), the current entrepreneurs identify just a few opportunities in their local environments. Still, a positive factor is the perception on the resources of the region, which are evaluated as good by both subsamples of respondents.

The Centre region is the one where we have the highest percentage of both potential and current entrepreneurs that are able to identify business opportunities in their local environment. Nevertheless, financial stability, actually the lack of financial predictability, is an important reason for which the employees are not willing to open a business. At the same time the same lack of financial predictability is a deterrent for 
current entrepreneurs as well to venture to set up a new business with the lowest percentages of those who intend to open a business.

The North East region is characterized by the lowest percentage of potential entrepreneurs willing to open a business, while on behalf of current business owners the percentage is average (compared with that registered for the other two regions). The reduced financial stability acts in a different way than in the Centre region, as in the region there is the lowest percentage of employees that see financial stability as an impediment for entrepreneurship. For current entrepreneurs a similar financial motivation seems to be present, probably due to a lower income level that makes financial motivation the most important one. The North-East region is the region with the highest percentages of respondents that signal the scarcity of financial and technological resources $(73.1 \%$, which is almost the double of the results obtained for the other regions). This comes to confirm an important development gap, especially in technological resources, as compared to the other two regions.

The regional differences in the intentions, motivations, barriers and limitations for entrepreneurship confirm the theoretical view that the personal motivations to become an entrepreneur are strongly determined by environmental conditions. Taking the view that entrepreneurship is a reflection of the local competitive advantages and disadvantages of the external environment the authors of the current study emphasize the need of a spatial approach to competitiveness. Regional differences should be taken into account in the elaboration of the further operational Action Plan of the Romanian National Competitiveness Strategy, obviously corroborated with the results of other similar studies. This will allow regions to play a significant role in the generation of economic and social welfare, while local needs would be much better satisfied and territorial imbalances reduced, in time.

Obviously, the authors are very much aware that this research is limited by a series of issues. Among those issues, some important ones are the lack of further data that could better explain the entrepreneurial behavior at regional levels and the lack of inclusion of other regions as well, in order to have a more complete view on the whole Romanian territory. The data base that was used in our study was collected within the activities of a European project and its structure and methodology were clearly determined by the project framework. In order to increase the reliability of such quantitative studies there is a clear need to continue them and to extend their coverage to all the regions of Romania. It would also be helpful for researchers and, mainly, for policy makers if they had continuous and reliable data offered by the National Institute of Statistics. The authors are also aware that future research would also need econometric modeling in order to understand the determinant causal factors of the entrepreneurial dynamics at regional level. Such on-going data collection and continuous research would clearly allow better informed answers for complex policy decision-making.

\section{References}

Antonescu, D. (2012), "Identificarea disparităţilor şi convergenţei economice regionale în Uuniunea Europeană și în România”, National Institute of Economic Research, Romanian Academy.

Armeanu, D., Istudor, N. and Lache, L. (2015), "The Role of SMEs in Assessing the Contribution of Entrepreneurship to GDP in the Romanian Business Environment", Amfiteatru Economic, Vol. 17, No. 38, pp. 195-211. 
MMCKS Arzeni, S. and Pellegrin, J.P., (1997), "Entrepreneurship and Local Development", The OECD Observer, No. 204 February/March.

408 Audretsch, D.B., Keilbach, M. and Evol, J. (2004), "Entrepreneurship and regional growth: an evolutionary interpretation". The Journal of Evolutionary Economics, Vol. 14, pp. 605-616.

Baptista, R., Escaria, V. and Madruga, P. (2008), "Entrepreneurship, regional development and job creation: the case of Portugal". Small Business Economics, Vol. 30, pp. 49-58.

Brancu, L., Guðmundsdóttir, S., Gligor, D. and Munteanu, V. (2015), "Is Culture a Moderator of Entrepreneurship Motivation? A Comparative Study of Romania and Iceland". Amfiteatru Economic, Vol. 17, No. 38, pp. 133-147.

Chelariu, C., Brashear, T. G., Osmonbekov, T. and Zait, A. (2008), "Entrepreneurial propensity in a transition economy: exploring micro-level and meso-level cultural antecedents". Journal of Business \& Industrial Marketing, Vol. 23, No. 6, pp. 405 415.

Cojanu, V. (2006), "Entrepreneurship and Regional Development in Romania". Studia Universitatis Babeş-Bolyai, Studia Europaea, Vol. LI, No. 2, pp.173-191.

Dodescu, A., Bădulescu, A., Giurgiu, A. and Pop-Cohuţ, I., (2011), "Women Entrepreneurship in the Western Romania. Research Results and Policy Recommendations". Theoretical and Applied Economics, Vol. XVIII, No. 1 (554), pp. 25-48.

Panc, I., Mihalcea, A. and Panc, T. (2012), "Entrepreneurship as a career choice for Romanian undergraduate students: who takes it from intention to action", Procedia - Social and Behavioral Sciences, Vol. 33, pp. 712 - 716.

Fotopoulos, G., (2012). "Nonlinearities in regional economic growth and convergence: the role of entrepreneurship in the European Union regions", The Annals of Regional Science, Vol. 48, pp. 719-741.

Greenfield, S., Stricken, A. and Aubey, R.T. (Eds.) (1979), "Entrepreneurs in cultural context", University of New Mexico Press.

Hatos, A., Hatos, R., Bădulescu, A. and Bădulescu, D. (2015), "Are Risk Attitudes and Individualism Predictors of Entrepreneurship in Romania?", Amfiteatru Economic, Vol 7, No. 38, pp. 148-161.

The European Commission Directorate-General Regional Policy (2003), "A Study on the Factors of Regional Competitiveness. A draft final report for Cambridge Econometrics.

Karlsson, Ch. and Dahlberg, R. (2003), "Entrepreneurship, firm growth and regional development in the new economic geography: Introduction", Small Business Economics, Vol. 21, No. 2, pp 73-76.

Lafuente, E.M. and Vaillant, Y. (2008), "Generationally Driven Influence of Role-Models On Entrepreneurship: 'Institutional Memory' in a Transition Economy", CEBR Working Paper Series, 03-2008, June.

Lafuente, E.M. and Rabetino, R. (2011). "Human capital and growth in Romanian small firms", Journal of Small Business and Enterprise Development, Vol.18, No. 1, pp. 7479.

Leff, N.H. (1979), "Entrepreneurship and economic development: the problem revisited", Journal of Economic Literature, Vol. 17, pp. 46-64.

Meyer, M., Libaers, D., Thijs, B., Grant, T., Glänzel, W. and Debackere, K. (2014), "Origin and emergence of entrepreneurship as a research field", Journal Scientometrics, Vol. 98, No. 1, pp 473-485. 
McClelland (1961), The Achieving Society, Princetown.

Mihalcea, A.D., Mitan A. and Viţelar, A. (2012), "Generation Y: Views on Entrepreneurship", Economia. Seria Management Vol. 15, No. 2.

Nemirschi, N. and Craciun, A. (2010), "Entrepreneurship and Tourism Development In Rural Areas: Case of Romania", Romanian Economic and Business Review, Vol. 5, No. 1, pp. 138-143.

Nicolae, M. and Ion, I. (2012 a), "Entrepreneurship Challenges in the European Union", Proceedings of the Best Form International Conference Pitești 26 - 29 April "Boosting Entrepreneurship Tools for Migrants”, pg. 145-151, Univesitatea din Pitești.

Nicolae, M. and Ion, I. (2012 b), "Entrepreneurship Perceptions in Romania: Where Do We Stand?", Review of International Comparative Management, Vol. 13, No. 2, May 2012 .

Noseleit, F. (2013), "Entrepreneurship, structural change, and economic growth", The Journal of Evolutionary Economics, Vol. 23, pp. 735-766.

Pennings, J.M. (1982), "The urban quality of life and entrepreneurship", Academy of Management Journal, Vol. 25, No. 1, pp. 63-79.

Porter, M.E., Delgado, M., Ketels, C. and Stern, S. (2008), "Moving to a New Global Competitiveness Index, The Global Competitiveness Report 2008-2009", World Economic Forum.

Stevenson, H. and Jarillor, C. (1990), "Paradigm Of Entrepreneurship: Entrepreneurial Management", Strategic Management Journal (1986-1998), Vol. 11, No. 5, pp.17-27. 